\title{
Pemberdayaan Lahan Tidur (Kebun PKK) dengan Tanaman Jagung Manis (Zea mays saccharata, Sturt) di Kelurahan Simpangtiga
}

\author{
Surtinah*, Niken Nurwati \\ Universitas Lancang Kuning \\ * surtinah@unilak.ac.id
}

\begin{abstract}
Abstrak. Lahan terbuka yang diprogramkan sebagai kebun PKK di Kelurahan Simpangtiga terlihat memprihatinkan, tidak ada tanaman budidaya yang di tanam di kebun tersebut. Kebun PKK yang digarap merupakan pekarangan warga yang tidak dimanfaatkan, tetapi pengelolaannya sangat terbatas. Kegiatan pemberdayaan kebun PKK tersebut dengan tanaman jagung manis menjadi salah satu alternatif untuk menjadikan lahan tersebut berdayaguna, dan berhasil guna. Metode yang digunakan adalah penyuluhan, demontrasi, pendampingan, dan evaluasi. Hasil yang diperoleh memperlihatkan bahwa Pengetahuan ibu-ibu PKK meningkat dengan kegiatan penyuluhan yang dilaksanakan, berdasarkan evaluasi kuisioner setelah kegiatan. Hasil yang diperoleh memperlihatkan bahwa kebun PKK yang dikelola dengan baik akan menghasilkan produksi pangan alternatif yang dapat memenuhi kebutuhan anggota PKK, dan dapat menjadi sumber pemasukan bagi kas organisasi. Pengelolaan kebun PKK yang berupa lahan tidur harus dirumuskan dengan suatu kebijakan dari aparat Kelurahan, sehinggan tidak muncul kepentingan pribadi setelah kebun PKK berhasil guna. Perlunya kesadaran masyarakat akan kebutuhan pangan keluarga yang tidak dibebankan kepada pemerintah, tetapi menjadi tanggungjawab masyarakat juga dengan mengelola sumber daya alam yang ada.
\end{abstract}

Kata kunci: lahan terbuka, kebun PKK, pemberdayaan, jagung manis

\section{PENDAHULUAN}

Lahan tidur yang terdapat di Kelurahan Simpangtiga, yang dimiliki oleh masyarakat dengan persetujuan pemilik dijadikan sebagai kebun PKK. Program ini dibuat dengan tujuan untuk memberdayakan lahan tidur tersebut, dan untuk menunjang program PKK. Kepemilikan kebun PKK tersebut hanya sekedar memenuhi persyaratan berdirinya suatu organisasi, kebun tersebut tidak digarap dan tidak diberdayakan. Anggota PKK Kelurahan Simpangtiga menyampaikan bahwa pemanfaatan kebun PKK yang mereka miliki tidak maksimal dan belum memnuhi kriteria teknik budidaya yang benar.

Kebun PKK yang berupa pekarangan warga tersebut bila diberdayakan dengan membudidayakan tanaman pangan seperti jagung manis maka akan sangat bermanfaat bagi anggota PKK yang terlibat di dalamnya. Melalui Program Pengabdian Kepada Masyarakat maka kegiatan pengelolaan kebun PKK itu dilaksanakan.

Peninjauan ke petani jagung yang ada di sekitar Kota Pekanbaru didapat informasi bahwa berapapun hasil panen maka akan terserap oleh pasar dengan harga jual yang tinggi, namun jagung yang diminta adalah varietas jagung manis. Para petani tidak usah repot pergi ke pasar menjual hasil panennya, karena para pedagang jagung bakarlah yang akan datang mencari bahan baku dagangannya ke lokasi budidaya dengan harga Rp. 1.500,- per tongkol. Dan itupun digunakan sistem ijon yang sangat menguntungkan petani, maksudnya dengan harga jual sesuai dengan harga pasar, pembayaran di muka hanya untuk mengantisipasi agar para pedagang mendapatkan bahan baku untuk dagangannya.

Dari evaluasi tenaga kerja, maka ibu-ibu yang tergabung dalam organisasi PKK RW 01 - RW 9, dapat melaksanakan proses budidaya jagung manis tersebut, karena ibu-ibu yang aktif di organisasi PKK tersebut merupakan ibu rumahtangga, kegiatan mereka selain ibu rumahtangga, hanya menghadiri arisan RT, olah raga, dan pengajian saja. Proses budidayanya mudah, tidak perlu keahlian khusus untuk melaksanakan budidaya jagung manis ini. Dari berbagai sudut pandang itulah maka tim menentukan untuk memberikan

To cite this article: Surtinah, dan N. Nurwati. 2019. Pemberdayaan Lahan Tidur (Kebun PKK) dengan Tanaman Jagung Manis (Zea mays saccharata, Sturt) di Kelurahan Simpangtiga. Unri Conference Series: Agriculture and Food Security 1: 84-87.

https://doi.org/10.31258/unricsagr.1a11 
pelatihan teknik budidaya jagung manis kepada ibu-ibu PKK di RW 01 - RW 9 Kelurahan Simpangtiga, Kecamatan Bukit Raya Kota Pekabaru. Tujuan Kegiatan ini adalah untuk menambah pengetahuan ibu-ibu dalam membudidayakan tanaman jagung manis yang mempunyai nilai jual tinggi, dan meningkatkan ketrampilan Ibu-ibu PKK Rw 01 - RW 09 dalam memberdayakan kebun PKK nya dengan optimal.

\section{KAJIAN PUSTAKA}

Nurwati dkk. (2016) melaporkan bahwa pangan yang memenuhi kecukupan gizi belum terpenuhi, sehingga dengan pemanfaatan pekarangan maka produksi pangan seperti ubi kayu, jagung, padi, kacang tanah, kacang hijau dapat digunakan untuk dibudidayakan, dan seluruh pihak harus terlibat di dalam pemberdayaan ini seperti pemerintah, akademisi, dan masyarakat.

Rumahtangga yang memiliki pekarangan luas, belum memanfaatkan pekarangan tersebut untuk menghasilkan bahan pangan, hanya 3\% dari responden yang memanfaatkan pekarangannya secara intensif, hal ini disebabkan karena kurangnya manis sesuai dengan namanya memiliki kadar gula yang cukup tinggi, sehingga rasanya lebih manis dari jagung biasa, namun ada juga varitas lokal yang memiliki pengetahuan masyarakat dalam mengelola pekarangannya menjadi pekarangan yang produktif (Nurwati et al., 2015). Jagung kadar gula $9-11 \%$, sedangkan varitas Hybrid Super Sweet Corn memiliki kadar gula $16-18 \%$. Jagung manis yang ditumpangsarikan denga kangkung sutera menghasilkan produksi yang dikategorikan baik, sehingga dengan mengaplikasikan tumpangsari pada lahan akan memperoleh dua produk pangan yang menguntungkan (Surtinah et al., 2016)

Varetas Bonanza merupakan varietas yang dapat dibudidayakan karena menghasilkan produksi yang paling tinggi dibandingkan dua varietas yang lain yaitu Sweet Boy dan Super Sweet (Surtinah, 2015). Hasil penelitian berikutnya dilaporkan bahwa varietas Bonanza dan Sweet Lady menunjukkan produksi yang berbeda tidak nyata sehingga kedua varietas dapat digunakan untuk dibudidayakan di Pekanbaru (Surtinah, 2018).

Pupuk dapat diberikan melalui daun, karena proses penyerapan unsur haranya berjalan lebih cepat dibanding pupuk yang diberikan lewat akar. Prajnanta (2004) menyatakan bahwa penyemprotan pupuk melalui daun, akan meningkatkan tekanan turgor. Tekanan turgor meningkat mengakibatkan sel-sel penjaga dari stomata menjadi penuh air dan mengakibatkan stomata terbuka, sehingga penyerapan larutan yang mengandung hara akan lebih mudah. Lingga dan marsono (2006) menyimpulkan pemberian pupuk melaui daun dipandang lebih berhasil dibandingkan dengan pemupukan lewat akar.

Sutejo (2002) dalam Surtinah (2006), menjelaskan bahwa pupuk daun mampu meningkatkan kegiatan fotosintesis dan daya angkut unsur hara dari dalam tanah ke dalam jaringan, mengurangi kehilangan Nitrogen dari jaringan daun, meningkatkan pembentukan karbohidrat, lemak dan protein, serta meningkatkan potensi hasil tanaman.

Surtinah (2007) melaporkan bahwa aplikasi lima macam pupuk melalui daun pada tanaman jagung manis memberikan hasil yang berbeda tidak nyata, sehingga disimpulkan bahwa pemberian pupuk melalui daun pada jagung manis dapat menghasilkan produksi jagung manis yang sama.

\section{METODE}

Metode yang digunakan untuk mencapai tujuan adalah: Penyuluhan: Pada kegiatan ini akan dijelaskan tentang fungsi kebun, dan jenis tanaman yang akan dibudidayakan. Pelatihan: pada kesempatan ini ibu-ibu diberikan pengetahuan tentang teknik pengolahan tanah, pemilihan komoditi, dan teknik budidaya. Pemberian bantuan: Setiap RW diberi bantuan 1 paket yang terdiri dari benih jagung manis, pupuk kandang, pupuk NPK, cangkul dan garu. Evaluasi: evaluasi dilakukan melalui kuesioner sebelum dan sesudah kegiatan penyuluhan. Pendampingan: selama kegiatan penanaman dilakukan pendampingan sampai panen. Penghargaan: penghargaan diberikan kepada kelompok PKK yang dinilai berhasil memanfaatkan kebun PKK nya menjadi produktif.

\section{HASIL DAN PEMBAHASAN}

Kegiatan pengabdian masyarakat yang diadakan sangat memuaskan, karena peserta yang hadir melebihi target yang diharapkan. Undangan yang hadir mencapai 60 orang, dan pada kegiatan tersebut Lurah Kelurahan Simpangtiga bersedia hadir dan memberikan kata sambutan, yang isinya mengharapkan agar kegiatan Pengabdian Masyarakat seperti ini sering-sering dilakukan di Kelurahan tersebut, agar pengetahuan 
dari masyarakat di Kelurahan Simpangtiga bertambah dengan ilmu-ilmu yang selama ini bukan merupakan bidang keahliannya.

Tingkat partisipasi yang begitu tinggi dari masyarakat Kelurahan Simpangtiga membangkitkan semangat Tim Pengabdian Masyarakat Faperta Unilak untuk terus meningkatkan kreatifitas dalam menggali potensi masyarakat yang membutuhkan bantuan dalam bidang ilmu Pertanian, maupun dalam bidang yang lain.

Antusias peserta dalam mengikuti kegiatan ini sangat membesarkan hati, hal ini tergambar dengan munculnya pertanyaan-pertanyaan tentang budidaya jagung manis, maupun tentang jagung manisnya sendiri. Begitu antusiasnya sehingga Tim Faperta Unilak harus membatasi audiens yang bertanya setiap RW diwakili oleh 1 (satu) orang saja untuk bertanya.

Hasil Pre test dan Post test yang kami lakukan untuk mengukur tingkat pengetahuan peserta tentang teknik budidaya jagung manis disajikan pada Tabel berikut ini.

Tabel 1. Hasil Kuisioner Sebelum dan Sesudah Kegiatan

\begin{tabular}{|c|c|c|c|c|c|c|}
\hline \multirow{2}{*}{ No. } & \multirow{2}{*}{ Kuisioner } & \multicolumn{2}{|c|}{ Sebelum (\%) } & \multicolumn{2}{|c|}{ Sesudah $(\%)$} & \multirow{2}{*}{ Meningkat } \\
\hline & & Tau & Tdk tau & Tau & Tdk tau & \\
\hline 1. & Peng. Tentang manfaat kebun PKK & 100 & - & 100 & - & 0 \\
\hline 2. & Tentang pengelolaan kebun PKK & 50 & 50 & 100 & - & 50 \\
\hline 3. & Ttg budidaya jagung manis & 35.71 & 64.29 & 100 & - & 64.29 \\
\hline 4. & Ttg manfaat jagung manis & 85.71 & 14.29 & 100 & - & 14.29 \\
\hline 5. & Minat membudidayakan jagung manis & 100 & - & 100 & - & 0 \\
\hline
\end{tabular}

Evaluasi berdasarkan kuisioner yang diperoleh dapat dijelaskan sebagai berikut, pengertian tentang manfaat kebun PKK tidak perlu diragukan lagi, seluruh peserta yang hadir paham tentang manfaat kebun PKK yang menjadi tanggung jawab mereka. Hanya 50\% saja yang memanfaatkan kebun PKK untuk dikelola, sedangkan 50\% sisanya sekedar mengetahui manfaat kebun tanpa berupaya untuk mengeksploitasi kebun tersebut.

Budidaya jagung manis bukanlah suatu hal yang sulit untuk dilaksanakan, dan $35.71 \%$ peserta pernah membudidayakan jagung manis, namun tidak mengikuti teknik budidaya yang dianjurkan, untuk menghasilkan jagung manis dengan kualitas yang baik. Dari peserta yang pernah membudidayakan jagung manis, diperoleh informasi, bahwa budidaya yang mereka lakukan adalah menanam dan mengambil hasil panen tanpa memperhatikan teknik budidayanya.

Penjelasan teknik budidaya jagung manis mengundang banyak pertanyaan dari peserta. Mereka sangat tertarik dan bersedia melaksanakannya di masing-masing RW, sebagai respon yang diberikan setelah mereka mengikuti kegiatan penyuluhan ini dilaksanakan. Ditinjau dari manfaat jagung manis, bahwa tanaman ini merupakan salah satu tanaman yang dapat menggantikan makanan pokok kita yaitu beras, karena kandungan gizinya cukup untuk memenuhi kebutuhan manusia. Sebagian besar peserta yaitu $85.71 \%$ tahu akan hal ini, oleh karena itu mereka sangat antusias untuk melaksanakan budidaya jagung manis ini.

Di akhir kegiatan pengabdian Masyarakat ini, Tim membuat suatu evaluasi dengan memberikan kuisioner serupa seperti sebelum kegiatan. Dan hasilnya terjadi peningkatan pengetahuan dari peserta, baik dalam pengelolaan kebun PKK, teknik budidaya jagung manis, dan manfaat jagung manis.

Hasil budidaya jagung manis yang diperoleh di RW 04 sangat memuaskan, kelompok PKK dengan memberdayakan lahan tidurnya $200 \mathrm{~m} 2$ dengan jarak tanam jagung manis yang digunakan $40 \times 25 \mathrm{~cm}$ dapat menghasilkan 2000 tanaman jagung manis dan tiap tanaman menghasilkan dua tongkol jagung manis yang siap jual, tiap tongkol dijual dengan harga Rp. 1.500 rupiah, maka mereka mendapatkan uang kas sebesar Rp. 6.000.000,- hasil dijual ke anggota PKK. Penanaman kedua dilakukan, tetapi muncul masalah tentang kepentingan pribadi, sehingga untuk kelanjutan budidaya jagung manis menjadi terkendala.

Setiawan (2017) melaporkan bahwa Rata-rata pendapatan keluarga yang berasal dari pekarangan sebesar Rp 507.500,- perbulan. Hal ini menggambarkan bahwa pekarangan yang berupa lahan tidur apabila dikelola dengan baik maka akan menjadi sumber pendapatan keluarga. Andrianyta, Ulfah, dan Hermawan (2016) melaporkan bahwa terjadi penghematan pengeluaran untuk pangan keluarga sebesar $25.46 \%$, sehingga pemanfaatan pekarangan rumah diarahkan kepada pemenuhan kebutuhan keluarga dan menambah penghasilan keluarga, yang dapat memperkuat ketahanan pangan keluarga. 


\section{KESIMPULAN}

Pengetahuan ibu-ibu PKK meningkat dengan kegiatan penyuluhan yang dilaksanakan, berdasarkan evaluasi kuisioner setelah kegiatan. Hasil yang diperoleh memperlihatkan bahwa kebun PKK yang dikelola dengan baik akan menghasilkan produksi pangan alternatif yang dapat memenuhi kebutuhan anggota PKK, dan dapat menjadi sumber pemasukan bagi kas organisasi. Pengelolaan kebun PKK yang berupa lahan tidur harus dirumuskan dengan suatu kebijakan dari aparat Kelurahan, sehinggan tidak muncul kepentingan pribadi setelah kebun PKK berhasil guna. Perlunya kesadaran masyarakat akan kebutuhan pangan keluarga yang tidak dibebankan kepada pemerintah, tetapi menjadi tanggungjawab masyarakat juga dengan mengelola sumber daya alam yang ada.

\section{UCAPAN TERIMA KASIH}

Terimakasih diucapkan kepada Pimpinan Universitas Lancang Kuning yang telah memberikan dana Pengabdian Kepada Masyarakat, dan Ketua LPPM Universitas Lancang Kuning yang telah memberikan fasilitas selama melaksanakan kegiatan PKM ini. Terimakasih juga diucapkan kepada mahasiswa yang terlibat dalam kegiatan PKM ini.

\section{DAFTAR PUSTAKA}

Andrianyta, H., A. Ulfah, dan H. Hermawan. 2016. Dampak Pemanfaatan Pekarangan dalam Perspektif Sosial dan Ekonomi di Kalimantan Timur. Prosiding Seminar Nasional Inovasi Teknologi Pertanian, Banjar Baru 17071017.

Nurwati, N., Mutryrny, M., dan Mufti. 2016. Analisis Kebutuhan Pangan di Kecamatan Rumbai Pesisir Kota Pekanbaru. Jurnal Agribisnis 18(1): 26- 33.

Nurwati, N., Surtinah, dan A. Masykur. 2015. Analisis Pemanfaatan Pekarangan untuk Mendukung Ketahanan Pangan di Kecamatan Rumbai Pesisir Kota Pekanbaru Yard Utilization Analysis in Support of Food Security in Rumbai Pesisir Pekanbaru. Jurnal Ilmiah Pertanian 11(2): 1-8.

Lingga dan Marsono. 2006. Petunjuk Penggunaan pupuk. Jakarta: Penebar swadaya.

Naviosade. 2007. Upaya Peningkatan Hasil dan Kualitas Tanaman Jagung Manis (Zea mays sacharata) Melaui Pupuk Kalium dan Pupuk Organik 24(2): 136-144.

Prajnanta, F. 2004. Melon, pemeliharaan secara Intensif, Kiat Sukses Beragribisnis. Jakarta: Penebar Swadaya.

Setiawan, A. 2017. Kontribusi Lahan Pekarangan terhadap Pendapatan Keluarga di Desa Triyoso Kecamatan Belitang Kabupeten Ogan Komering Ulu Timur Tahun 2017. Skripsi pada Program Studi Pendidikan Geografi Jurusan Pendidikan Ilmu Pengetahuan Sosial Fakultas Keguruan dan Ilmu Pendidikan Universitas Lampung. Tidak dipublikasikan.

Surtinah, S. 2006. Peranan Plant Catalyst 2006 dalam Meningkatkan Produksi Sawi (Brassica juncea, L). Jurnal Ilmiah Pertanian 3(1): 6-16.

Surtinah, S. 2007. Menguji 5 Macam Pupuk Daun dengan Mengukur Kadar Gula Total Biji Jagung Manis (Zea mays saccharata). Jurnal Ilmiah Pertanian 3(2): 1-6.

Surtinah, S. 2015. Pengujian Tiga Varietas Jagung Manis (Zea mays Saccharata) di Rumbai Kota Pekanbaru. Jurnal Ilmiah Pertanian 12(1): 37-43.

Surtinah, S., N. Susi, dan S.U. Lestari. 2016. Optimasi Lahan dengan Sistem Tumpang Sari Jagung Manis (Zea mays Saccharata, Sturt) dan Kangkung Sutra (Ipomea Reptans) di Pekanbaru. Jurnal Ilmiah Pertanian 12(2): 62-72.

Surtinah, S. 2018. Agronomic Performance of Sweet Corn (Zea mays Saccharata, Sturt) in Rumbaidistrict Pekanbaru. Agroland: The Agricultural Sciences Journal 5(1): 53-58 